\title{
How Did We Get to Inflation Targeting and Where Do We Need to Go to Now? A Perspective from the U.S. Experience
}

\author{
Daniel L. Thornton
}

\begin{abstract}
The Federal Reserve is not formally inflation targeting. Nevertheless, it is commonly believed to be an implicit inflation targeter. The evolution to inflation targeting occurred because central banks, most importantly the Federal Reserve, demonstrated that monetary policy could control inflation. As central banks' credibility for keeping inflation low increased, policy actions became increasingly focused on affecting the growth rate of employment or the unemployment rate. The author argues that this change in emphasis is unlikely to generate positive benefits; more importantly, it endangers the continued effectiveness, and perhaps even the viability, of inflation targeting. (JEL E31, E52, E58)
\end{abstract}

Federal Reserve Bank of St. Louis Review, January/February 2012, 94(1), pp. 65-81.

\section{INTRODUCTION}

This article provides a perspective on the evolution to inflation targeting based on economic theory and the U.S. experience. The Federal Reserve is not formally inflation targeting. Nevertheless, it is commonly believed to be an implicit inflation targeter. While the analysis presented here is based largely on the U.S. experience, I believe that it applies broadly to all central banks.

The economics profession has made considerable progress towards understanding the role of central banks in controlling inflation in the 45 years since I took my first economics course. Until at least the early 1970s the majority of the economics profession believed that central banks could do little to control inflation. Conventional wisdom had it that monetary policy was relatively ineffective for controlling inflation or for economic stabilization. Fiscal policy, not monetary policy, was the principal way that governments could stabilize the economy and keep inflation low, by filling the gap between private demand and potential output. I review the evolution of economic thought from "there is little central banks can do to control inflation" to "inflation targeting."

Daniel L. Thornton is a vice president and economist at the Federal Reserve Bank of St. Louis.

This article is reprinted from Twenty Years of Inflation Targeting: Lessons Learned and Future Prospects, edited by David Cobham, Øyvind Eitrheim, Stefan Gerlach, and Jan F. Qvigstad. Copyright @ 2010 Cambridge University Press. Reprinted with permission.

( ) 2012, The Federal Reserve Bank of St. Louis. The views expressed in this article are those of the author(s) and do not necessarily reflect the views of the Federal Reserve System, the Board of Governors, or the regional Federal Reserve Banks. Articles may be reprinted, reproduced, published, distributed, displayed, and transmitted in their entirety if copyright notice, author name(s), and full citation are included. Abstracts, synopses, and other derivative works may be made only with prior written permission of the Federal Reserve Bank of St. Louis. 


\section{Thornton}

My thesis is that policymakers' belief in the efficacy of monetary policy for inflation control changed dramatically in spite of the fact that there was no fundamental refutation of what I call the monetary policy ineffectiveness proposition (MPIP). The evolution to inflation targeting occurred because central banks, most importantly the Federal Reserve, demonstrated that monetary policy could control inflation. It was not a consequence of fundamental advancements in the profession's understanding of how monetary policy affects the economy. Consequently, the profession and policymakers returned, perhaps reluctantly, to the Phillips curve framework for conducting monetary policy. I argue that this framework endangers the continued effectiveness, and perhaps even the viability, of inflation targeting. I then recommend three steps that inflationtargeting central banks should take to preserve and strengthen inflation targeting.

\section{THE MONETARY POLICY INEFFECTIVENESS PROPOSITION}

It is difficult to envisage a central banker who would have recommended inflation targeting in the 1950s and 1960s. As Cagan (1978, p. 85) points out, "The quantity of money was not considered important, indeed was hardly worth mentioning, for questions of aggregate demand, unemployment, and even inflation." This view of monetary policy's effectiveness extended well into the early 1970s. Just as today, the conventional view of inflation was that it was caused by an excess of aggregate demand at or near the "full employment" level of output. The MPIP was the belief that monetary policy had relatively little effect on aggregate demand; unable to affect aggregate demand, there was little that monetary policy could do to control inflation.

The MPIP has several components. 1 Important among these is the belief that monetarypolicy-induced changes in the money supply have little or no direct effect on aggregate demand. The theoretical basis for the direct link between the supply of money and prices is the quantity theory of money, or, more simply, the equation of exchange. As today, the quantity theory was widely viewed as a tautology, rather than an economic theory. 2 It was agreed that, if the central bank simply handed everyone money, prices would increase; this was not how central banks increased the money supply, however. Policy-induced changes in the money supply were a consequence of open market operations, discount window lending, and changes in reserve requirements. These actions would have an immediate effect on bank reserves and, hence, short-term interest rates. Critics argued that a policy-induced increase in the supply of money would cause interest rates to fall, which would in turn increase the quantity of money demanded. The effect of an increase in the money supply would be largely offset by an endogenous decline in money's velocity. Consequently, there would be little or no effect on aggregate demand and, hence, on prices or output. $\underline{3}$

The effectiveness of monetary policy is determined by the extent to which monetary policy actions affect interest rates-not the supply of money. The so-called interest rate channel of monetary policy was also thought to be relatively weak. Evidence suggested that consumption and investment spending were relatively interest-inelastic. Consequently, the monetary authority would have to produce a relatively large change in interest rates to have a significant impact on aggregate demand. Investment decisions were determined more by expectations of future earnings than by interest rates. Changes in the interest rate not accompanied by changes in expectations about the economy would be of little consequence for aggregate demand. Some thought that the efficacy of monetary policy might be asymmetric: Reducing interest rates during a period 
of economic slack would be less effective than raising interest rates during a period of economic expansion. $\underline{4}$ Monetary policy, it was said, cannot push on a string.

This tenet of the MPIP was reinforced by the fact that monetary policy actions only directly affect very short-term rates. Spending decisions were thought to be determined by the behavior of long-term rates, however; but central banks' ability to affect long-term rates was problematic.

The last 50 years have done little to change economists' and central bankers' views about the basic tenets of the MPIP. As of 2009 the supply of money is thought to be inconsequential, consumption and investment spending are thought to be interest-inelastic, short-term rates are thought to be relatively unimportant for spending, and the monetary authority's ability to influence long-term rates remains questionable.

Acknowledging that there is little agreement "on exactly how monetary policy exerts its influence" on the real economy, Bernanke and Gertler (1995, p. 27) note that the conventional model, whereby "monetary policymakers use their leverage over short-term interest rates to influence the cost of capital and, consequently, spending on durable goods, such as fixed investment, housing, inventories and consumer durables," is incomplete in several important ways. Important among these is the fact that "empirical studies of supposedly 'interest-sensitive' components of aggregate spending have in fact had great difficulty in identifying a quantitatively important effect of the neoclassical cost-of-capital variable." This evidence motivated Bernanke and Gertler (and others) "to explore whether imperfect information and other 'frictions' in credit markets might help explain the potency of monetary policy" (Bernanke and Gertler, 1995, p. 28; emphasis added). $\frac{5}{}$ One such attempt is called the credit channel of monetary policy, which has two separate channels: the "balance sheet" channel and the "bank lending" channel. 6 The balance sheet channel suggests that restrictive monetary policy increases the wedge between the cost of internal finance and that of external finance. Specifically, monetary-policy-engineered increases in short-term interest rates adversely affect the value of potential borrowers' assets, their cash flow, and, consequently, their creditworthiness. This increases the external finance premium. For small borrowers, the external finance premium increases by more than the rise in short-term rates. While heterogeneity is important for the effect of changes in interest rates on firms and individuals, the empirical importance of the balance sheet channel for the macroeconomy is unclear (see, for example, Hubbard, 1995). $\underline{?}$

The bank credit channel (see, for example, Bernanke and Blinder, 1988; Bernanke, 1993; and Gertler and Gilchrist, 1993), which asserts that restrictive monetary policy actions have a direct effect on bank lending, is generally recognized (see, for example, Thornton, 1994, and Bernanke, 2007) to be "quantitatively unimportant," because banks have access to external funds that are not constrained by the availability of reserves. ${ }^{-}$

Economists continue to believe that long-term rates, not short-term rates, matter for spending decisions (see, for example, Blinder et al., 2001; Woodford, 2001; Broaddus, 2002; Freedman, 2002; and Eggertsson and Woodford, 2003). Many economists and policymakers believe that central bank actions have a limited effect on long-term rates, however. For example, in his July 20, 1993, congressional testimony, Chairman Greenspan noted: "Currently, short-term rates, most directly affected by the Federal Reserve, are not far from zero; longer-term rates, set primarily by the market, are appreciably higher" (Greenspan, 1993; emphasis added).

Conventional wisdom sees central banks influencing longer-term rates in accordance with the expectations hypothesis $(\mathrm{EH})$ of the term structure of interest rates. The $\mathrm{EH}$ asserts that the 


\section{Thornton}

long-term rate is determined by the market's expectation for the short-term rate over the maturity of the long-term asset plus a constant risk premium. The risk premium compensates investors for the higher degree of market risk associated with holding longer-term assets. The empirical evidence against the EH is overwhelming (see, for example, Campbell and Shiller, 1991; Sarno, Thornton, and Valente; 2007; and Della Corte, Sarno, and Thornton, 2008; and the references cited therein). ${ }^{-}$Nevertheless, because the ability of central banks to affect long-term rates in accordance with the $\mathrm{EH}$ depends on the predictability of the short-term rate and the duration for which the market believes the rate will stay at that level, a number of central banks have attempted to provide "forward guidance" about their policy rate.

As was the case with inflation targeting, the Reserve Bank of New Zealand took the lead. It began announcing a path for its policy rate in 1997. Norway followed in 2005, Sweden in 2007. It is thought that announcing the path for its policy rate permits the central bank to "steer" expectations. Irma Rosenberg, the first deputy governor of the Riksbank, Sweden's central bank, suggested in 2007 that, "by affecting expectations of short-term interest rates, we as the central bank can also indirectly affect interest rates with a slightly longer duration, which in turn increases the effect of monetary policy" (Rosenberg, 2007; see also Gjedrem, 2006). Rudebusch (2007), Goodhart and Lim (2008), and Andersson and Hofmann (2010), however, show that forward guidance has not increased the predictability of the path of the policy rate beyond a few months.

The Federal Reserve was a latecomer here. In response to a presentation by Rudebusch on monetary policy inertia (see, for example, Woodford, 1999) at the January 2003 Federal Open Market Committee (FOMC) meeting, the then governor of the Federal Reserve System, Ben Bernanke, asked Rudebusch "if there had been evidence on whether or not the responsiveness of long-term interest rates to movements in the fed funds rate was consistent with the predictability of the type" proposed by Woodford (FOMC transcripts; January 28-29, 2003, p. 31). Rudebusch responded that he did not "think we have the empirical evidence of monetary policy inertia" (for a description of his argument and evidence, see Rudebusch, 2007). Bernanke suggested that this meant only that it had not been tried: "There should be more [inertia in the policy rule] in order to get more effect on long-term rates. I think that's an open question" (FOMC transcripts; January 28-29, 2003, p. 32).

The Fed's first attempt at providing forward guidance came in August 2003. At the June 2003 FOMC meeting, Bernanke responded to several Committee members who voiced reservations about the Fed's ability to influence longer-term interest rates by saying (FOMC transcripts; June 24-25, 2003, pp. 45-46):

If the policy is one in which we essentially try to lower the whole path of long-term interest rates and we enforce that with a package of complementary actions that includes trying to manage expectations along the term structure and taking a series of other actions such as purchasing long-term bonds and other kinds of instruments, I think that's one of the first things we ought to be doing. I believe that would actually work and would in fact be a good approach.

Consistent with Bernanke's suggestion, the August 2003 FOMC policy statement included the sentence "In these circumstances, the Committee believes that policy accommodation can be maintained for a considerable period." $\underline{10}$ At the September meeting, Alan Greenspan said he thought it a "mistake" to include the sentence (FOMC transcripts, September 16, 2003, p. 80). 


\section{Figure 1}

\section{The Yield Curve Announcement Effect, 2009}

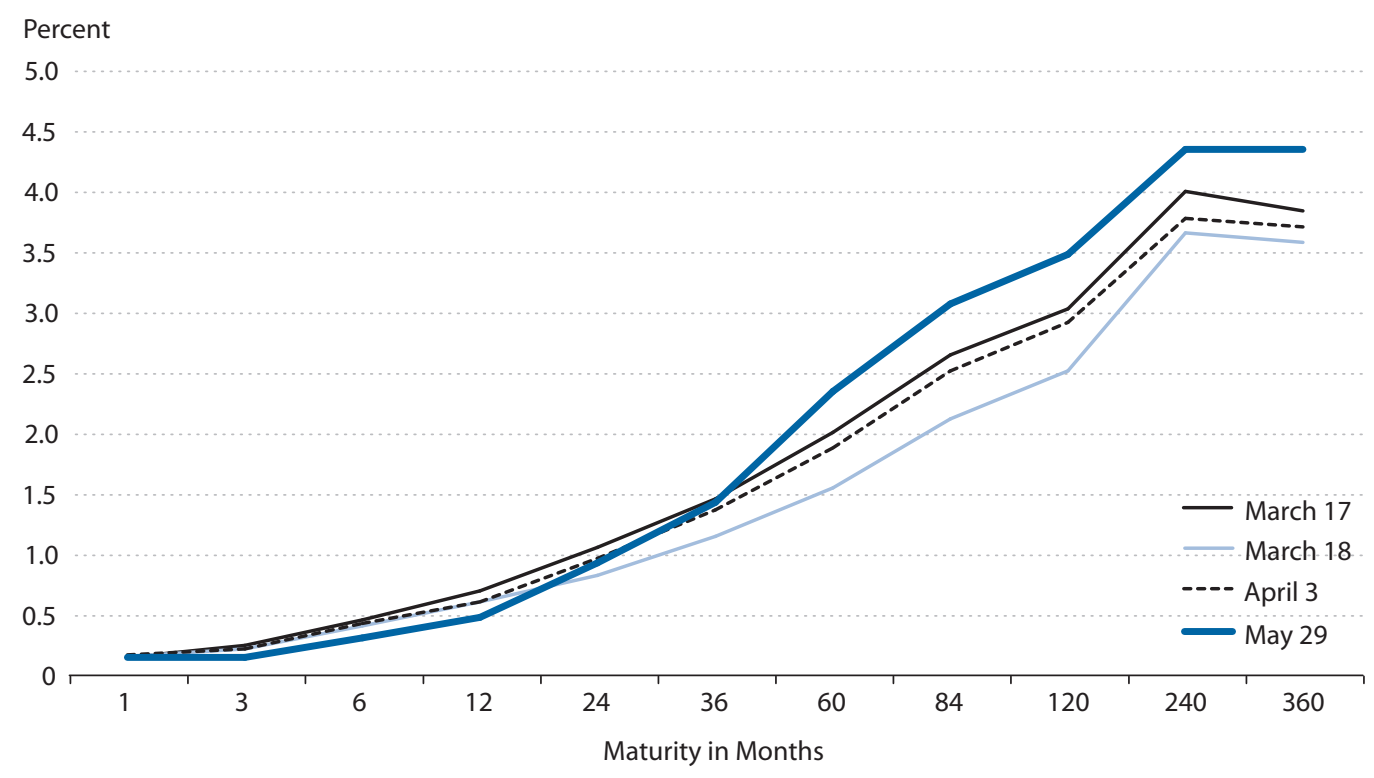

Despite the concern among some members about the usefulness of forward guidance language, the FOMC's May 2004 statement read "The Committee believes that policy accommodation can be removed at a pace that is likely to be measured," suggesting the FOMC might start increasing its target for the federal funds rate at the next meeting (Board of Governors press release, May 6, 2004). 11 The FOMC began increasing the funds rate from the then historically low level of 1.0 percent at its June 2004 meeting and by 25 basis points at each of its next 16 meetings. Forward guidance was dropped at the December 2005 meeting.

Forward guidance had relatively little effect on long-term rates. Not only did yields on longerterm securities generally increase from August 2003 to June 2004, but the yields across the term structure increased despite the historically low and unchanged target for the funds rate and the FOMC's commitment to keep the funds rate low. Moreover, longer-term rates declined during the first few months following the initial target increases in 2004. Indeed, Greenspan (2005) termed the fact that longer-term rates edged lower despite the 150-basis-point increase in the funds rate target a "conundrum." 12

The Fed's next attempt with forward guidance occurred at the March 17-18, 2009, meeting, when it implemented the Eggertsson and Woodford (2003) strategy, which Bernanke had out-

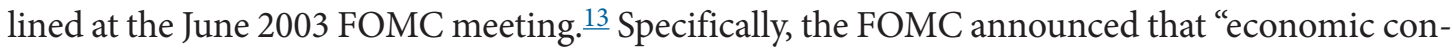
ditions are likely to warrant exceptionally low levels of the federal funds rate for an extended period" and that the Fed would purchase "up to $\$ 300$ billion of Treasury securities over the next six month" (Board of Governors press release, March 18, 2009).

This attempt was also unsuccessful. While there was an immediate "announcement effect" as yields on 10-year Treasuries and most other long-term securities declined by about 50 basis 


\section{Thornton}

Figure 2

\section{European Inflation Rates, 1970-85}

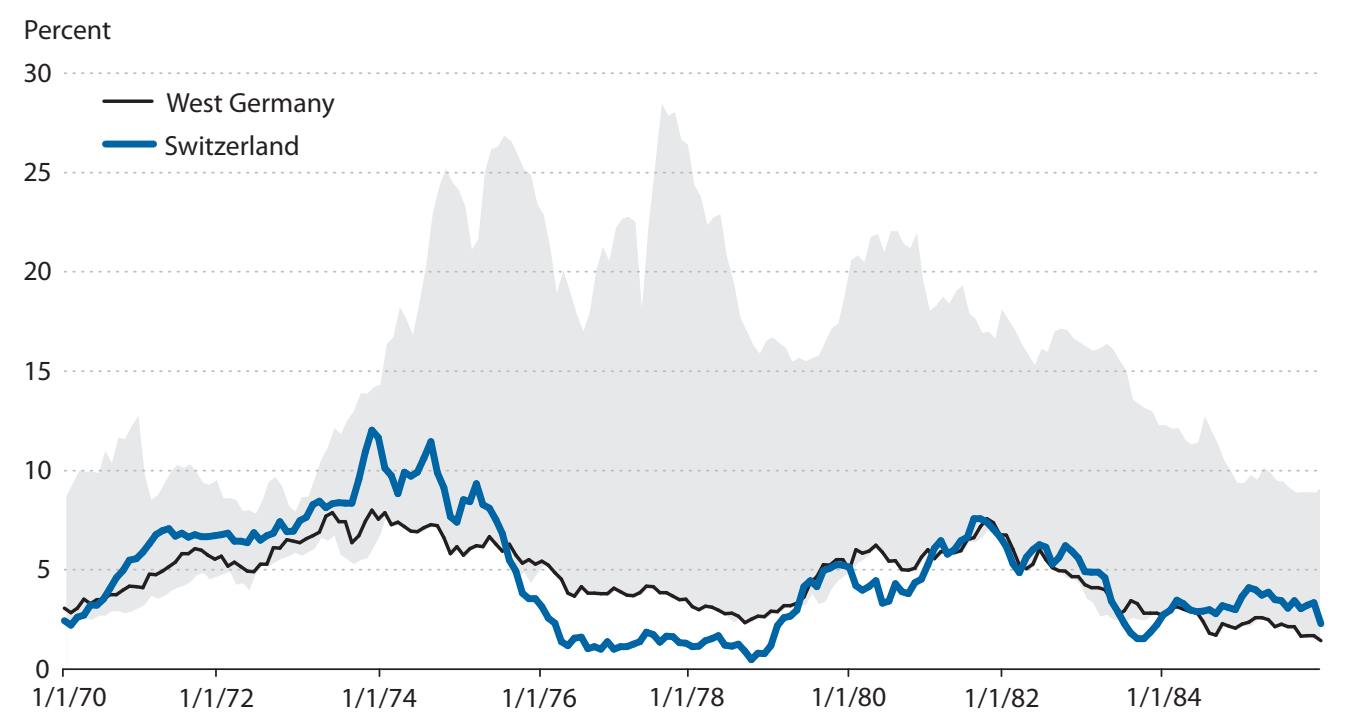

NOTE: The shaded area shows the range of low-to-high inflation rates in 12 European countries.

points on March 18, the marked flattening of the yield curve, shown in Figure 1, was short-lived. Figure 1 shows that the announcement effect had essentially vanished by April 6, 2009. By July 27 the yield was considerably steeper than it had been on March 17. This experience is consistent with a high degree of substitutability across assets with differing maturities and suggests that the Fed's ability to influence the behavior of long-term rates is limited at best.

Finally, there is little to indicate that the economics profession has changed its view about the effectiveness of changes in monetary and reserve aggregates. Indeed, Svensson (2007, p. 4) suggests that, over the past 50 years, economists have learned that "monetary aggregates matter little, or even not at all, for monetary policy." The lack of importance of money is reflected in the fact that money is not explicit in the canonical New Keynesian model, which is commonly used to evaluate monetary policy. $\underline{14}$

\section{The Evolution to Inflation Targeting}

Skepticism about the ability of central banks to control inflation vanished despite essentially unchanged views about how monetary policy affects the economy. Consequently, it is natural to ask "What then caused the dramatic shift towards inflation targeting?" It is seldom, if ever, true that such an event is attributable to a single factor. Indeed, I believe a number of factors, in some way or another, contributed to the shift. Nevertheless, three factors or events were critical. The first, and most important, was the demonstration that central banks can control inflation. The cornerstone event was Paul Volcker's decision to reduce inflation by focusing on monetary aggregates. Inflation was in double digits when Volcker became Chairman of the Federal Reserve in 
1979 and about 4 percent when he departed in 1987. This remarkable experience demonstrated beyond reasonable doubt that central banks could control inflation. $\underline{15}$

The West Germans and Swiss also affected perceptions of inflation control. Both central banks were committed to keeping inflation low (Rich and Bèguelin, 1985; Kohli and Rich, 1986; von Hagen, 1999), and both emphasized monetary aggregates in the conduct of monetary policy. Moreover, both countries fared much better than most of their European counterparts. This is illustrated in Figure 2, which compares the year-on-year CPI [consumer price index] inflation rates for West Germany and Switzerland to the envelope (the shaded area) of the lowest and highest monthly inflation rates of 12 European countries in the period 1970 to 1985 . 16 West German inflation was low relative to the other countries over the entire period. Swiss inflation was in the middle of the range until the mid-1970s, but at or well below the envelope from the mid-1970s onwards. Had the United States continued on its high-inflation path, it is possible that these experiences would have led to inflation targeting. At a bare minimum, the U.S. experience accelerated the evolution to inflation targeting.

My second event is likely to be controversial. Nevertheless, I believe it to be extremely important, at least in the United States. Beginning around 1970 the United States went from having cyclically balanced budgets, except during wars, to having what was, by the standards of the time, large and persistent deficits. The practice of running large, persistent deficits played an important role in the shift to inflation targeting, because it took countercyclical fiscal policy out of the policy mix. With fiscal policy sidelined, the reduction in inflation and, perhaps more importantly, the subsequent Great Moderation could be attributed only to monetary policy. Had the government continued to conduct activist countercyclical fiscal policy, the relative importance of monetary and fiscal policy for inflation control and economic stabilization would have been less clear. Even those who continued to embrace the tenets of the MPIP conceded that monetary policy was effective, even if they were not exactly sure how it worked (such as Bernanke and Gertler, 1995, p. 28, talking about the desire to "explain the potency of monetary policy"). $\underline{17}$

A third factor that deserves credit for the shift to inflation targeting is the insightful "impossibility theorem" known as the Lucas critique. Lucas's work was motivated by the "mysterious transformation" of an "obvious fallacy [a permanent Phillips curve trade-off] to the cornerstone of the theory of economic policy" (Lucas, 1976, p. 19). Economists were quick to understand that Lucas's insight meant (i) that any effort to reduce inflation permanently had to be credible and (ii) that credible disinflation might be achieved at a lower cost (Sargent, 1983). There is little doubt that credibility played an important role in the Fed's decision to announce its intentions (Lindsey, Orphanides, and Rasche, 2005, and Goodfriend, 2007). Moreover, the need for a credible commitment is a cornerstone of inflation targeting-i.e., the announcement of a specific numerical inflation target.

Given that (i) inflation has been significantly reduced by monetary policy actions and (ii) no change had occurred in their understanding of how monetary policy worked, the economics profession and policymakers fell back on the pre-monetary-policy-appears-to-work inflation paradigm - the Phillips curve. The modern version of the Phillips curve paradigm takes the general form

$$
\pi_{t+1}=E_{t} \pi_{t+1}-\beta y_{t}
$$




\section{Thornton}

where $E_{t} \pi_{t+1}$ denotes the expected rate of inflation, $y_{t}$ denotes some measure of economic slack (e.g., the gap between potential and actual output, or the gap between the actual unemployment rate and the nonaccelerating inflation rate of unemployment [NAIRU]), and the coefficient $\beta$ is strictly positive (note that equation (6.1) implies that the long-run Phillips curve is vertical). Inflation-targeting central banks anchor inflation by announcing a numerical inflation target to establish $E_{t} \pi_{t+1}$. Of course, the inflation target must be credible. This requires the central bank to take actions to keep inflation close enough to the target. Because the only thing that determines inflation, given inflation expectations, is the degree of slack in the economy, policymakers have to adjust their policy instrument to changes in the measure of slack even if they have no specific objective for stabilizing the real economy-even if they are what the then deputy governor of the Bank of England, Mervyn King (1997), referred to as "inflation nutters."

The profession and policymakers have adopted this framework despite still believing that changes in short-term rates should have a relatively small impact on aggregate demand. Moreover, they adhere to the Phillips curve framework despite the facts that (i) the Phillips curve framework provides relatively poor forecasts of future inflation and (ii) the marginal contribution of the slack measures to in-sample or out-of-sample inflation forecasts is small (see, for example, Atkeson and Ohanian, 2001; FOMC transcripts, June 25-26, 2002; Fisher, Liu, and Zhou, 2002; and Stock and Watson, 2008).

\section{Implications for Inflation Targeting}

I believe that the return to the Phillips curve framework may be a problem for the continued success, and even the viability, of inflation targeting. $\underline{18}$ There are three main threats. The first is the increasing belief in the need for central banks to have a "dual mandate." Meyer (2004) makes a distinction between a dual mandate-in which "monetary policy is directed at promoting both full employment and price stability, with no priority expressed" - and a hierarchical mandatein which "price stability is identified as the principal objective, and central banks are restricted in pursuing other objectives unless price stability has been achieved" (Meyer, 2004, p. 151; emphasis added). It is important to note that (i) monetary policy affects only aggregate demand and (ii) the appropriate monetary policy response to aggregate demand shocks is invariant to inflation or output stabilization; when there are shocks to aggregate demand, inflation stabilization and output stabilization are complements, not substitutes (Svensson, 2007, p. 3). For example, Bernanke (2004) notes that "the ultimate source of this long-run trade-off [between the variance of prices and the variance of output] is the existence of shocks to aggregate supply." As a result, having a dual mandate means that policymakers should promote both full employment and price stability when confronted with shocks to aggregate supply. Is this possible? Bernanke (2004) describes the problem:

According to conventional analysis, an increase in the price of oil raises the overall price level (a temporary burst in inflation) while depressing output and employment. Monetary policymakers are therefore faced with a difficult choice. If they choose to tighten policy (raise the short-term interest rate) in order to offset the effects of the oil price shock on the general price level, they may well succeed-but only at the cost of making the decline in output more severe. Likewise, if monetary policymakers choose to ease in order to mitigate the effects of the oil price shock on output, their action will exacerbate the inflationary impact. Hence, in the 
standard framework, the periodic occurrence of shocks to aggregate supply (such as oil price shocks) forces policymakers to choose between stabilizing output and stabilizing inflation.

Bernanke appears to suggest that the answer is "No." What should policymakers do? If the shock is temporary (a temporary oil price shock), it might be best to do nothing. If the shock is permanent, nothing might still be the best option, since there is no way for monetary policy to affect aggregate supply, and the effect on inflation will be temporary, as the price level adjusts to a permanent new higher or lower level. This policy choice is reinforced by monetary policy neutrality. In any event, just how and under what circumstances policymakers should respond to aggregate supply shocks is unclear.

Moreover, in a thoughtful analysis of the causes of the Great Moderation, Bernanke (2004) describes four ways that improved price stability has reduced the volatility of output (see also Taylor, 2008). If long-run price stability generates greater economic stability for the reasons Bernanke suggests, and perhaps others, it is difficult to understand why policymakers would sacrifice price stability in order to offset temporarily the effect of a permanent adverse supply shock on output and employment. $\underline{19}$

While most inflation-targeting central banks do not appear to give equal weight to economic stability and price stability, many (perhaps all) follow a hierarchical mandate-the second threat to inflation targeting. Meyer (2004, p. 151) indicates that "inflation-targeting countries today have moved away from the initially austere implementation, more in line with the spirit of a hierarchical mandate, and have become flexible inflation targeters, close cousins of dual mandate central banks." Consistent with Meyer's statement, the former deputy governor of the Reserve Bank of New Zealand [RBNZ], Murray Sherwin, has noted that the RBNZ has moved along the "spectrum between what Svensson refers to as 'strict' and 'flexible' inflation targeting" (Sherwin, 1999). The danger of a hierarchical mandate for inflation targeting comes from three sources. First, while both economic theory and experience suggest that central banks can achieve price stability, there are important reasons to be skeptical of central bankers' ability to stabilize output around potential. This skepticism is embedded in the MPIP and supported by empirical evidence. For example, Rasche and Williams' (2007) review of the empirical literature of the effectiveness of monetary stabilization policy "failed to determine a major role for monetary policy in short-run stabilization" (2007, pp. 469, 474).

Indeed, much of the evidence that monetary policy actions affect the real economy comes from a handful of episodes in which an economic recession appears to be "caused" by a monetary contraction (see Rasche and Williams, 2007, for a discussion of these "case studies"). Such episodes provide no basis for believing that monetary policy can successfully stabilize the economy. Moreover, because they are one-sided, these episodes are not a basis for concluding that expansionary monetary policy can significantly increase output.

Successful economic stabilization policy requires a good, or at least reliable, measure of potential output. It is widely accepted, however, that potential output is difficult if not impossible to measure (see Orphanides, 2003, and the references cited therein, and the July/August 2009 issue of the Federal Reserve Bank of St. Louis Review (volume 91, issue 4), entitled "Projecting Potential Growth: Issues and Measurements"). A failure to have good and reliable measures of the output gap or NAIRU can result in destabilizing policy errors. Indeed, Orphanides (2004) 


\section{Thornton}

argues that overemphasis on the output gap and its mismeasurement contributed significantly to the Great Inflation.

At a more fundamental level, economic theory suggests that the conventional "steady-state" definition of potential output, which is commonly used by policymakers to construct the output gap and the NAIRU, is ill-suited for economic stabilization policy. The policy-relevant definition is "the rate of output the economy would have if there were no nominal rigidities, but all other (real) frictions and shocks were unchanged" (Basu and Fernald, 2009, p. 3). .0 This policy-relevant definition accounts for the effect of supply shocks on potential output. $\underline{21}$ Consequently, even if the conventional definition of the output gap could be measured precisely, monetary policy actions based on it run a significant risk of being destabilizing.

Successful stabilization policy also depends on the ability of policymakers to forecast what would happen if they did nothing. Economic forecasting has always been difficult, and forecasting economic turning points, which is critical to successful economic stabilization policy, is particularly difficult. This is evidenced by the significant lag in dating both the beginning and end of recessions. $\underline{\underline{22}}$ There is considerable evidence that both survey and econometric forecasts have considerable difficulty improving upon naïve forecasts. This has been particularly true since the mid-1980s (Atkeson and Ohanian 2001; Tulip 2005; d'Agostino, Giannone, and Surico, 2006; Campbell, 2007; Stock and Watson, 2007, 2008; d'Agostino and Whelan, 2008). $\underline{23}$

The inability to make accurate forecasts beyond very short horizons means that it will be very difficult, if not impossible, for policymakers to anticipate the longer-run consequences of their actions. For example, the FOMC reduced its funds rate target to the then historically low level of 1.0 percent at the June 2003 meeting and kept the target at 1.0 percent until the June 2004 meeting. The staff had revised up its forecast for the output gap for 2003 and 2004 at the previous meeting, noting that "[a]ny serious delay in the recovery...would imply a larger output gap... and by our analysis would result in an even lower inflation rate" (FOMC transcripts; May 6, 2003, p. 13). The presumption was that the FOMC would reduce the funds rate target at the June meeting unless there was new evidence. Governor Ferguson summarized the evidence, noting that "the output gap still closes relatively slowly...the unemployment rate hangs up above the NAIRU through next year [and]...core PCE [personal consumption expenditure] even before the adjustment stays at what I would consider to be the very low end of an acceptable range" (FOMC transcripts, June 24-25, 2003, p. 130). The funds rate target was reduced to the then historically low level of 1.0 percent, while several members had a desire or a willingness to accept a larger cut. Only President Moskow voiced concern about the action, saying: "Of course the data we talk about are always looking backward, and the key is the forecast going forward. As we've often said in these meetings, sometimes the last cut or the last increase in the funds rate target is the one that's not needed because we didn't have perfect information at the time we made that cut or increase" (FOMC transcripts; June 24-25, 2003, p. 153).

By the December 2003 meeting the data suggested that the economy had grown by 3.3 percent in the second quarter and at an extremely rapid rate of 8.2 percent in the third quarter. Greenspan summarized the situation (FOMC transcripts; December 9, 2003, pp. 88-89) by noting that

it has almost invariably been the case that the Federal Reserve would tighten under such conditions. Indeed, preemption is something that has filtered its way into the monetary policy lexicon. The issue of preemption implies, of course, that we will adjust our policy ahead of anything 
that we can readily foresee. In current circumstances, therefore, there is and there will continue to be a lot of pressure on us to move rates higher. We have resisted because of a quite considerable and significant difference in the present economy from what we have observed in the past. In recent decades, the turning point toward accelerating economic activity usually occurred when the inflation rate was 3 percent or 4 percent, sometimes even higher, and the necessity for preemption was critically obvious. The problem with preemption, though it is something that is very interesting to observe in retrospect, is that it doesn't necessarily follow that we are preempting future developments that will actually occur the way we expect. So, we have to be careful not to try to preempt something that is not fairly likely to happen. There is a risk and indeed a cost to being wrong.

No one expressed concern about the longer-run consequences of what was recognized as an excessively easy policy. ${ }^{24}$ Even though inflation had increased substantially and by December the FOMC had acknowledged that "the probability of an unwelcome fall in inflation has diminished in recent months and now appears almost equal to that of a rise in inflation" (Board of Governors press release, December 9, 2003), the FOMC did not increase the target until June 2004.

The FOMC was effectively pursuing a hierarchical mandate. With inflation in check, presumably because of well-anchored inflation expectations, the FOMC was free to pursue its objective of "maximum sustainable economic growth." Taylor and others have suggested that "this extra-easy policy was responsible for accelerating the housing boom and thereby ultimately leading to the housing bust" (Taylor, 2009b, pp. 343-44).

While there will undoubtedly be much analysis and debate over the Fed's role, the decline in housing prices and the resulting financial market turmoil generated an unprecedented monetary policy response. Initially, the Fed attempted to ease credit conditions by simply reallocating credit (see, for example, Thornton, 2009). $\underline{25}$ When the Fed was no longer able to sterilize the effects of its credit allocation program on the monetary base, the base increased rapidly to an unprecedented level. The massive quantitative easing has generated concerns of future inflation (see, for example, Taylor, 2009a). As President Broaddus noted at the June 2003 FOMC meeting, "Common sense tells us...that a determined expansion of the monetary base has to be effective against deflation at the zero bound. If that were not the case, we could eliminate all taxes, and the government could permanently finance its operations with money creation alone" (FOMC transcripts; June 24-25, 2003, p. 35). $\underline{26}$ What the ultimate verdict will be is uncertain. That the Fed's behavior was motivated by a hierarchical mandate is not. $\underline{27}$

Policymakers appear to have replaced their belief in a permanent Phillips curve trade-off with the belief that "a little inflation is good for economic growth" - which is the third threat to inflation targeting. Most policymakers believe that the long-run Phillips curve is vertical, which implies that the same long-run real outcome can be achieved with zero inflation as it can with 2 or 3 percent inflation. Nonetheless, most policymakers also profess that the "optimal," "appropriately measured," inflation rate is positive. The theoretical justification for the various hypotheses that motivate the belief that a little inflation is good for economic growth is highly questionable or simply unsound (Marty and Thornton, 1995). Nevertheless, many policymakers believe that "inflation can be too low as well as too high" (Meyer, 2004, p. 160). $\underline{28}$

The belief that positive inflation is somehow optimal is reflected in the fact that all inflationtargeting central banks have a nonzero inflation target. It is also consistent with the fact that 


\section{Thornton}

nearly all inflation-targeting central banks have a recent inflation performance that is in the upper end of their target ranges. It could be that central bankers might simply believe that the inflation measures they target overestimate the true unobservable inflation rate. It seems unlikely, however, that the bias is large enough to explain the observed behavior.

\section{IMPLICATIONS FOR INFLATION-TARGETING CENTRAL BANKS}

The analyses in the previous sections have implications for the evolution of inflation targeting. First and foremost, inflation-targeting central banks should be dissuaded from having a dual mandate. If they decide to have a dual mandate, they should inform the public of this policy and the rationale for adopting it.

Second, inflation-targeting central banks should carefully and honestly evaluate the extent to which they can effectively stabilize the real economy around potential output. This analysis should provide a realistic assessment of their ability to measure potential output, the extent to which they believe inflation is related to the output gap, and the other impediments to successful economic stabilization discussed above, as well as some others not discussed here (such as lags in the effect of policy actions on the economy). The end product of this analysis should be a statement indicating the extent to which the inflation-targeting central bank believes that it can pursue a hierarchical mandate.

Third, inflation-targeting central banks should engage in a serious dialog with their constituents about the optimal rate of inflation. In particular, if they believe that the appropriately measured, long-run inflation rate is positive, they should state the reasons for this belief.

\section{NOTES}

1 There was also a belief that inflation was caused by "cost-push" factors, not amenable to monetary policy actions (see, for example, Nelson, 2005). For example, Arthur Burns attributed inflation to a variety of "special factors." As these special factors dissipated, but inflation did not, Burns blamed inflation on government deficits (Hetzel, 1998). Hence, cost-push inflation was not an essential element of the MPIP.

$\underline{2}$ Cagan $(1978$, p. 86) notes that "textbooks in basic economics and even in money and banking mentioned the quantity theory of money, if at all, only to hold it up to ridicule."

3 Monetarists made two attempts at incorporating money into the canonical model. One was to suggest that money affects aggregate demand through a "wealth effect."The other was the buffer-stock model of money demand. The profession was not impressed.

4 Another reason is that, if the central bank reduces the money supply, individuals are forced to alter their behavior. On the other hand, if the central bank increases the supply of money, individuals can simply hold the money in idle balances.

$\underline{5}$ In essence, Bernanke and Gertler (1995) are saying that we know monetary policy is efficacious, we just don't know why. The credit channel of monetary policy, as it is called, is an attempt to provide a theoretical basis for the belief in the efficacy of monetary policy. See also Bernanke (2007).

6 Skepticism over the interest rate channel also arose out of the Great Inflation and Sargent and Wallace's (1975) demonstration that interest rate targeting can lead to price level indeterminacy. McCallum (1981) changed that by demonstrating that indeterminacy can be eliminated if policymakers have a "nominal anchor"-i.e., if policymakers care about inflation.

7 The lack of empirical support for the interest rate channel of money policy led some analysts (such as Mishkin, 1995; Meltzer, 1995; and Taylor, 1995) to broaden the financial asset price channel of monetary policy to include exchange rates, equity prices, and even land prices. There has been relatively little interest in or empirical support for these alternative asset price channels of monetary policy, however. 
8 Bernanke (2007) also suggests that restrictive monetary policy may affect banks by increasing the external finance premium paid by banks in much the same way that the balance sheet channel is thought to affect individuals and firms. He does not say why restrictive monetary policy will increase banks' external finance premium, however. The spread between the equivalent-term London Interbank Offered Rate (LIBOR) (the rate at which banks lend to each other) and the certificate of deposit (CD) rate (the rate at which banks borrow externally) has been small historically.

9 One reason for the empirical failure of the expectations hypothesis is that conventional tests of the EH are based on the assumption that the expected future short-term rate deviates from the actual future short-term interest rate by a white noise error. Interest rates are notoriously difficult to predict, however. The empirical failure of the $\mathrm{EH}$ is probably a consequence of the incompatibility of the assumption upon which tests of the $\mathrm{EH}$ are based and the unpredictability of interest rates (see, for example, Guidolin and Thornton, 2008).

10 This sentence was not voted on by the Committee. Rather, at the conclusion of a lengthy discussion of the sentence, Greenspan took a vote of all FOMC participants. The vote was 11 to 7 in favor of the sentence. Greenspan concluded, "On the basis of that vote it's right on the margin. But I would say that we have to put in the truncated version of the final sentence" (FOMC transcripts; August 12, 2003, p. 95).

11 The Committee considered several courses of action, including dropping the sentence. However, the sentence appeared unchanged in both the September and October FOMC statements. On a suggestion from Greenspan, the sentence was modified at the December 2003 meeting. Most thought that Greenspan's rewording made the statement more "conditional." Four participants expressed a preference for removing the statement, however.

12 Elsewhere (Thornton, 2007) I show that there was a marked break in the relationship between the overnight funds rate and the 10-year Treasury yield that predates the conundrum period. Moreover, it coincides with the FOMC switch from using the funds rate as an operational target to using it as a policy target. I hypothesize that the change in behavior reflects the fact that the FOMC, and not the market, began determining the path for the funds rate in the late 1980 s. I also present evidence to support this hypothesis.

13 Eggertsson and Woodford (2003, p. 200) note that the "effect [on long-term yields] follows not from the purchases themselves, but from how they are interpreted," but that purchases may help overcome "private sector skepticism about whether the history-dependent interest rate policy will actually be followed."

14 McCallum (2001, p. 146) argues that money is implicit because "the central bank's control over the one-period nominal interest rate ultimately stems from its ability to control the quantity of base money in existence." He suggests, however, that the "error thereby introduced [by omitting money] is extremely small" (2001, p. 150). This conclusion is not surprising, because money has no effect on economic activity, except through its effect on the interest rate. Hence, there is little difference in money being implicit or explicit in such models (see, for example, Leahy, 2001).

15 Others share my view, such as Goodfriend $(2007$, p. 8).

16 The countries are Austria, Belgium, Denmark, Finland, France, Italy, Luxembourg, the Netherlands, Norway, Spain, Sweden, and the United Kingdom.

17 A contributing factor was the experience of the Great Depression, which made economists and policymakers skeptical of the self-equilibrating nature of market economies. With fiscal policy sidelined and little or no faith in the self-correcting nature of market economies, the experience of the Great Moderation led many economists to conclude that monetary policy was much more effective than previously thought. The monetary and fiscal response to the most recent financial market turmoil suggests that policymakers remain skeptical of the self-equilibrating nature of market economies and the ability of existing institutions to deal with the current "crisis" (see, for example, Miron 2009).

18 For evidence on the success of inflation targeting, see Rasche and Williams (2007), Rogers (2010), and Schmidt-Hebbel (2010).

19 This point is directly related to the theoretically correct measure of the output gap, which is discussed later.

$\underline{20}$ For estimates of the theoretically correct output gap, see Nelson and Neiss (2005).

21 The idea that aggregate supply shocks reduce potential output relative to its steady-state level is not new. For example, see Rasche and Tatom (1977) and the references therein.

$\underline{22}$ For example, the NBER [National Bureau of Economic Research] dating committee announced on December 2, 2008, that the recession began in December 2007.

$\underline{23}$ Reifschneider and Tulip (2007) analyze the forecasting accuracy of the FOMC, the Greenbook (produced before each meeting of the FOMC), the Congressional Budget Office, the administration, the Blue Chip Consensus forecast, and the Survey of Professional Forecasters short-run forecasts of GDP growth, the unemployment rate, and CPI inflation over the period 1986 to 2006. Their estimates suggest that, with the exception of the unemployment rate, the forecasts provide little information beyond that contained in the historical average. 


\section{Thornton}

$\underline{24}$ Greenspan noted that "the current federal funds rate is well below any estimate of the equilibrium rate. That is, when we start to raise the rate, we may have the problem of having to return to the equilibrium rate relatively quickly" (FOMC transcripts; December 9, 2003, p. 91).

$\underline{25}$ Taylor (2009a) calls this "industrial policy."

$\underline{26}$ Arthur Burns, Fed chairman from 1970 to 1978, had a similar belief. At the March 18-19, 1974, FOMC meeting, Burns noted that, while he was "not a monetarist, he found a basic and inescapable truth in the monetarist position that inflation could not have persisted over a long period of time without a highly accommodative monetary policy" (FOMC Memorandum of Discussion, March 18-19, 1974, pp. 110-12).

27 This danger associated with a hierarchical mandate is exacerbated by political pressures. In his Per Jacobsson Lecture, which was delivered just six days prior to Volcker's dramatic change in the FOMC's monetary policy, Burns (1979, p. 15) noted prophetically that "the Federal Reserve System had the power to abort the inflation at its incipient stage fifteen years ago or at any later point, and it has the power to end it today. At any time within that period, it could have restricted the money supply and created sufficient strains in the financial and industrial markets to terminate inflation with little delay" but political pressures limited the "practical scope for restrictive actions."

$\underline{28}$ In addition, at the June 2003 FOMC meeting Governor Bernanke, as he was then, stated:"I think the May 6 statement left the mistaken impression with some that the Fed was concerned about the threat of imminent deflation as opposed to what really concerned us - namely, the possibility of a decline in inflation to a level that, while below the desirable range, would still be greater than zero" (FOMC transcripts; June 24-25, 2003, p. 131; emphasis added).

\section{REFERENCES}

Andersson, Magnus and Hoffman, Boris. "Gauging the Effectiveness of Quantitative Forward Guidance: Evidence from Three Inflation Targeters," in David Cobham, Øyvind Eitrheim, Stefan Gerlach, and Jan F. Qvigstad, eds., Twenty Years of Inflation Targeting: Lessons Learned and Future Prospects. Chap. 15. Cambridge, UK: Cambridge University Press, 2010, pp. 368-97.

Atkeson, Andrew and Ohanian, Lee. "Are Phillips Curves Useful for Forecasting Inflation?" Federal Reserve Bank of Minneapolis Quarterly Review, Winter 2001, 25(1), pp. 2-11.

Basu, Susanto and Fernald, John G. "What Do We Know (And Not Know) About Potential Output?" Federal Reserve Bank of St. Louis Review, July/August 2009, 91(4), pp. 187-214; http://research.stlouisfed.org/publications/review/09/07/Basu.pdf.

Bernanke, Ben S. "Credit in the Macroeconomy." Federal Reserve Bank of New York Quarterly Review, Spring 1993, 18(1), pp. 50-70; www.ny.frb.org/research/quarterly_review/1993v18/v18n1article6.pdf.

Bernanke, Ben S. "The Great Moderation." Speech at the meeting of the Eastern Economic Association, Washington, DC, February 20, 2004; www.federalreserve.gov/boarddocs/speeches/2004/20040220/default.htm.

Bernanke, Ben S. "The Financial Accelerator and the Credit Channel." Speech at the "Credit Channel of Monetary Policy in the Twenty-First Century" conference, Federal Reserve Bank of Atlanta, June 15, 2007; www.federalreserve.gov/newsevents/speech/bernanke20070615a.htm.

Bernanke, Ben S. and Blinder, Alan S. "Credit, Money, and Aggregate Demand." American Economic Review, May 1988, 78(2), pp. 435-39.

Bernanke, Ben S. and M. Gertler. "Inside the Black Box: The Credit Channel of Monetary Policy Transmission." Journal of Economic Perspectives, Fall 1995, 9(4), pp. 27-48.

Blinder, Alan S.; Goodhart, Charles; Hildebrand, Philipp M.; Lipton, David A. and Wyplosz, Charles. How Do Central Banks Talk? Geneva: International Center for Monetary and Banking Studies, 2001.

Board of Governors of the Federal Reserve System. Press releases, various dates; www.federalreserve.gov/newsevents/default.htm.

Broaddus, J. Alfred Jr. "Transparency in the Practice of Monetary Policy." Federal Reserve Bank of St. Louis Review, July/August 2002, 84(4), pp. 161-66; http://research.stlouisfed.org/publications/review/02/07/155-166PanelDiscussion.pdf.

Burns, Arthur F. “The Anguish of Central Banking." Per Jacobsson Lecture, Belgrade, September 30, 1979; www.perjacobsson.org/lectures/1979.pdf.

Cagan, Phillip. "Monetarism in Historical Perspective," in Thomas Mayer, ed., The Structure of Monetarism. New York: W. W. Norton, 1978, pp. 85-93. 
Campbell, John Y. and Shiller, Robert J. "Yield Spreads and Interest Rate Movements: A Bird's Eye View." Review of Economic Studies, May 1991, 58(3), pp. 495-514.

Campbell, Sean D. "Macroeconomic Volatility, Predictability, and Uncertainty in the Great Moderation: Evidence from the Survey of Professional Forecasters." Journal of Business and Economic Statistics, April 2007, 25(2), pp. 191-200.

D’Agostino, Antonello; Giannone, Domenico and Surico, Paolo. "(Un)Predictability and Macroeconomic Stability." Working Paper No. 605, European Central Bank, April 2006; http://econpapers.repec.org/paper/ecbecbwps/20060605.htm.

D'Agostino, Antonello and Whelan, Karl. "Federal Reserve Information During the Great Moderation." Journal of the European Economic Association, April-May 2008, 6(2-3), pp. 609-20.

Della Corte, Pasquale; Sarno, Lucio and Thornton, Daniel L. "The Expectation Hypothesis of the Term Structure of Very ShortTerm Rates: Statistical Tests and Economic Value." Journal of Financial Economics, July 2008, 89(1), pp. 158-74.

Eggertsson, Gauti B. and Woodford, Michael. "The Zero Bound on Interest Rates and Optimal Monetary Policy." Brookings Papers on Economic Activity, 2003, 34(1), pp. 139-211.

Federal Open Market Committee. Meeting transcripts, various years; www.federalreserve.gov/monetarypolicy/fomc historical.htm.

Federal Open Market Committee. Memorandum of discussion, March 18-19, 1974; http://fraser.stlouisfed.org/historicaldocs/1651/download/51207/fomcmod19740319.pdf.

Fisher, Jonas D.M.; Liu, Chin T. and Zhou, Ruilin. "When Can We Forecast Inflation?” Federal Reserve Bank of Chicago Economic Perspectives, 2002, Q1, pp. 32-44; www.chicagofed.org/digital_assets/publications/economic_perspectives/2002/1qepart4.pdf.

Freedman, Charles. "The Value of Transparency in Conducting Monetary Policy." Federal Reserve Bank of St. Louis Review, July/August 2002, 84(4), pp. 155-60; http://research.stlouisfed.org/publications/review/02/07/155-166PanelDiscussion.pdf.

Gertler, Mark and Gilchrist, Simon. "The Role of Credit Market Imperfections in the Monetary Transmission Mechanism: Arguments and Evidence." Scandinavian Journal of Economics, March 1993, 95(1), pp. 43-64.

Gjedrem, Svein. "Monetary Policy in Norway." Speech presented at Norges Bank's Conference on Monetary Policy 2006 "Evaluating Monetary Policy," Oslo, March 30, 2006; www.bis.org/review/r060405b.pdf.

Goodfriend, Marvin. "How the World Achieved Consensus on Monetary Policy." NBER Working Paper No. 13580, National Bureau of Economic Research, November 2007; http://econpapers.repec.org/paper/nbrnberwo/13580.htm.

Goodhart, Charles A.E. and Lim, Wen B. "Interest Rate Forecasts: A Pathology." London School of Economics Discussion Paper No. 612, May 2008; http://eprints.Ise.ac.uk/24431/1/dp612.pdf.

Greenspan, Alan. "Testimony of Alan Greenspan, Chairman, Federal Reserve Board," in Monetary Policy Objectives: Midyear Review of the Federal Reserve Board. Washington, DC: Federal Reserve, July 20, 1993, pp. 3-13.

Greenspan, Alan. "Testimony of Chairman Alan Greenspan before the Committee on Banking, Housing, and Urban Affairs, U.S. Senate." Washington, DC, February 16, 2005.

Guidolin, Massimo and Thornton, Daniel L. "Predictions of Short-Term Rates and the Expectations Hypothesis of the Term Structure of Interest Rates." Working Paper No. 977, European Central Bank, December 2008.

Hetzel, Robert L. "Arthur Burns and Inflation." Federal Reserve Bank of Richmond Economic Quarterly, Winter 1998, 84(1), pp. 21-44; www.richmondfed.org/publications/research/economic quarterly/1998/winter/pdf/hetzel.pdf.

Hubbard, R. Glenn. "Is There a 'Credit Channel' for Monetary Policy?" Federal Reserve Bank of St. Louis Review, May/June 1995, 77(3), pp. 63-77; http://research.stlouisfed.org/publications/review/article/3172.

King, Mervyn. "Changes in U.K. Monetary Policy: Rules and Discretion in Practice." Journal of Monetary Economics, June 1997, 39(1), pp. 81-97.

Kohli, Uhrich and Rich, Georg. "Monetary Control: The Swiss Experience." Cato Journal, Winter 1986, 5(3), pp. 911-26; www.cato.org/pubs/journal/cj5n3/cj5n3-14.pdf.

Leahy, John V. “Commentary." Federal Reserve Bank of St. Louis Review, July/August 2001, 83(4), pp. 161-63; http://research.stlouisfed.org/publications/review/01/05/161-164Leahy.qxd.pdf.

Lindsey, David E.; Orphanides, Athanasios and Rasche, Robert H. "The Reform of October 1979: How It Happened and Why." Federal Reserve Bank of St. Louis Review, March/April 2005, 87(2 Part 2), pp. 187-236;

http://research.stlouisfed.org/publications/review/05/03/part2/Lindsey.pdf. 


\section{Thornton}

Lucas, Robert Jr. "Econometric Policy Evaluation: A Critique." Carnegie-Rochester Conference Series on Public Policy, January 1976, 1(1), pp. 19-46.

Marty, Alvin L. and Thornton, Daniel L. "Is There a Case for 'Moderate' Inflation?" Federal Reserve Bank of St. Louis Review, January/February 1995, 76(1), pp. 31-49; http://research.stlouisfed.org/publications/review/95/07/Moderate Jul Aug1995.pdf.

McCallum, Bennett T. "Price Level Determinacy with an Interest Rate Policy Rule and Rational Expectations." Journal of Monetary Economics, November 1981, 8(3), pp. 319-29.

McCallum, Bennett T. "Monetary Policy Analysis in Models Without Money." Federal Reserve Bank of St. Louis Review, July/August 2001, 83(4), pp. 145-60; http://research.stlouisfed.org/publications/review/01/05/145-160McCallum.qxd.pdf.

Meltzer, Allan H. "Monetary, Credit and (Other) Transmission Processes: A Monetarist Perspective." Journal of Economic Perspectives, Fall 1995, 9(4), pp. 49-72; www.jstor.org/stable/2138390.

Meyer, Laurence H. "Practical Problems and Obstacles to Inflation Targeting." Federal Reserve Bank of St. Louis Review, July/August 2004, 86(4), pp. 151-60; http://research.stlouisfed.org/publications/review/04/07/Meyer.pdf.

Miron, Jeffrey. "In Defense of Doing Nothing." Cato's Letter, Spring 2009, 7(2), pp. 1-7; www.cato.org/pubs/catosletter/catosletterv7n2.pdf.

Mishkin, Frederic. "Symposium on the Monetary Transmission Mechanism." Journal of Economic Perspectives, Fall 1995, 9(4), pp. 3-10.

Nelson, Edward. "The Great Inflation of the Seventies: What Really Happened?" Advances in Macroeconomics, 2005, 5(1), article 3; www.bepress.com/bejm/advances/vol5/iss1/art3.

Nelson, Edward and Neiss, Katharine S. "Inflation Dynamics, Marginal Cost, and the Output Gap: Evidence from Three Countries." Journal of Money, Credit, and Banking, December 2005, 37(6), pp. 1019-45.

Orphanides, Athanasios. “The Quest for Prosperity Without Inflation.” Journal of Monetary Economics, April 2003, 50(3), pp. 633-63.

Orphanides, Athanasios. "Monetary Policy Rules, Macroeconomic Stability and Inflation: A View from the Trenches." Journal of Money, Credit, and Banking, April 2004, 36(2), pp. 151-75.

Rasche, Robert H. and Tatom, John A. "The Effects of the New Energy Regime on Economic Capacity, Production, and Prices." Federal Reserve Bank of St. Louis Review, May 1977, 59(5), pp. 2-12; https://research.stlouisfed.org/publications/review/77/05/Energy May1977.pdf.

Rasche, R., and Williams, Marcela M. "The Effectiveness of Monetary Policy." Federal Reserve Bank of St. Louis Review, September/October 2007, 89(5), pp. 447-89; http://research.stlouisfed.org/publications/review/article/6054.

Reifschneider, David and Tulip, Peter. "Gauging the Uncertainty of the Economic Outlook from Historical Forecasting Errors." Finance and Economics Discussion Paper No. 2007-60, Federal Reserve Board, November 19, 2007; www.federalreserve.gov/pubs/feds/2007/200760/200760pap.pdf.

Rich, Georg and Béguelin, Jean-Pierre. "Swiss Monetary Policy in the 1970s and 1980s: An Experiment in Pragmatic Monetarism," in Karl Brunner and Robert E. Weintraub, eds., Monetary Policy and Monetary Regimes. Rochester, NY: Center for Research in Government Policy and Business, University of Rochester, 1985, pp. 76-111.

Roger, Scott. "Inflation Targeting at Twenties: Achievements and Challenges," in David Cobham, Øyvind Eitrheim, Stefan Gerlach, and Jan F. Qvigstad, eds., Twenty Years of Inflation Targeting: Lessons Learned and Future Prospects. Chap. 4. Cambridge, UK: Cambridge University Press, 2010, pp. 25-56.

Rosenberg, Irma. "Monetary Policy and the Riksbank's Communication." Speech delivered in Stockholm, August, 10, 2007; www.riksbank.com/templates/Page.aspx?id=25855.

Rudebusch, Glenn D. "Monetary Policy Inertia and Recent Fed Actions." Federal Reserve Bank of San Francisco Economic Letter, Number 2007-03; January 26, 2007; www.frbsf.org/publications/economics/letter/2007/el2007-03.pdf.

Sargent, Thomas J. "The Ends of Four Big Inflations," in Robert E. Hall, ed., Inflation: Causes and Effects. Chicago: University of Chicago Press, 1983, pp. 41-97.

Sargent, Thomas J. and Wallace, Neil. "'Rational' Expectations, the Optimal Monetary Instrument, and the Optimal Money Supply Rule." Journal of Political Economy, April 1975, 83(2), pp. 241-54.

Sarno, Lucio; Thornton, Daniel L. and Valente, Giorgio. "The Empirical Failure of the Expectations Hypothesis of the Term Structure of Bond Yields." Journal of Financial and Quantitative Analysis, March 2007, 42(1), pp. 81-100. 
Schmidt-Hebbel, Klaus. "Inflation Targeting Twenty Years On: Where, When, Why, With What Effects, and What Lies Ahead?" in David Cobham, Øyvind Eitrheim, Stefan Gerlach, and Jan F. Qvigstad, eds., Twenty Years of Inflation Targeting: Lessons Learned and Future Prospects. Chap. 5. Cambridge, UK: Cambridge University Press, 2010, pp. 57-89.

Sherwin, M. "Inflation Targeting: 10 Years On." Speech delivered at the New Zealand Association of Economists Conference, Rotorua, July 1, 1999; www.rbnz.govt.nz/speeches/0077458.html.

Stock, James H. and Watson, Mark W. "Why Has U.S. Inflation Become Harder to Forecast?" Journal of Money, Credit, and Banking, 2007, 39(1), pp. 3-33.

Stock, James H. and Watson, Mark W. "Phillips Curve Inflation Forecasts." NBER Working Paper No. 14322, National Bureau of Economic Research, September 2008; http://econpapers.repec.org/paper/nbrnberwo/14322.htm.

Svensson, Lars E.O. "What Have Economists Learned About Monetary Policy over the Past 50 Years?" Speech presented at the conference "Monetary Policy over Fifty Years," Frankfurt, September 21, 2007, on the occasion of the 50th anniversary of the Deutsche Bundesbank; www.riksbank.com/templates/Page.aspx?id=25785.

Taylor, John B. "The Monetary Transmission Mechanism: An Empirical Framework." Journal of Economic Perspectives, Fall 1995, 9(4), pp. 11-26.

Taylor, John B. "Better Living through Monetary Economics." Unpublished manuscript, Stanford University, February 2008; www.stanford.edu/ johntayl/Better\%20Living\%20Through\%20Monetary\%20Economics.pdf.

Taylor, John B. "The Need to Return to a Monetary Framework." Unpublished manuscript, Stanford University, January 2009a; http://research.stlouisfed.org/econ/bullard/Taylor2009January3.pdf.

Taylor, John B. "Economic Policy and the Financial Crisis: An Empirical Analysis of What Went Wrong." Critical Review, 2009b, 21(2-3), pp. 341-64.

Thornton, Daniel L. "Financial Innovation and Deregulation and the 'Credit View' of Monetary Policy." Federal Reserve Bank of St. Louis Review, January/February 1994, 76(1), pp. 31-49; http://research.stlouisfed.org/publications/review/94/01/Innovation_Jan_Feb1994.pdf.

Thornton, Daniel L. "The Unusual Behavior of the Federal Funds and 10-Year Treasury Rates: A Conundrum or Goodhart's Law?" Working Paper No. 2007-39, Federal Reserve Bank of St. Louis, September 2007, revised August 2010; http://research.stlouisfed.org/wp/2007/2007-039.pdf.

Thornton, Daniel L. "The Fed, Liquidity, and Credit Allocation." Federal Reserve Bank of St. Louis Review, January/February 2009, 91(1), pp. 13-21; http://research.stlouisfed.org/publications/review/09/01/Thornton.pdf.

Tulip, P. “Has Output Become More Predictable? Changes in Greenbook Forecast Accuracy." Finance and Economics Discussion Paper No. 2005-31, Federal Reserve Board, 2005; www.federalreserve.gov/pubs/feds/2005/200531/200531pap.pdf.

von Hagen, Jurgen. "Money Growth Targeting by the Bundesbank." Journal of Monetary Economics, June 1999, 43(3), pp. 681-701.

Woodford, Michael. "Optimal Monetary Policy Inertia." Manchester School, 1999, 67(Suppl. 1), pp. 1-35.

Woodford, Michael. "Monetary Policy in the Information Economy." NBER Working Paper No.8674, National Bureau of Economic Research, December 2001; http://econpapers.repec.org/paper/nbrnberwo/8674.htm. 


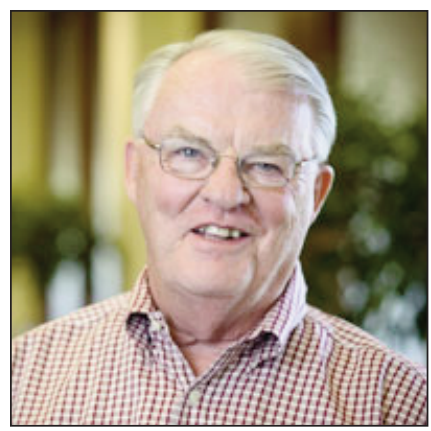

\section{Daniel L. Thornton}

Vice president and economic adviser, Federal Reserve Bank of St. Louis

http://research.stlouisfed.org/econ/thornton/

\section{Research Focus}

Dan Thornton analyzes financial markets, interest rates, and monetary policymost recently, the Fed's policy innovations of quantitative easing and the Term Auction Facility in the wake of the financial crisis.

\section{Recent Research}

"The Effectiveness of Unconventional Monetary Policy: The Term Auction Facility." Federal Reserve Bank of St. Louis Review, November/December 2011, 93(6), pp. 439-54.

"The FOMC's Interest Rate Policy: How Long Is the Long Run?" Federal Reserve Bank of St. Louis Economic Synopses, 2011, No. 29.

"A Perspective on Financial Market Reform," International Center for Banking and Corporate Governance, 2010.

"The Unusual Behavior of the Federal Funds Rate and Treasury Yields: A Conundrum or an Instance of Goodhart's Law?" Federal Reserve Bank of St. Louis Working Paper 2007-039C, updated August 2010. 